\title{
COMPARATIVE PERFORMANCE BETWEEN GENETICALLY IMPROVED AND TRADITIONAL SILVER BARB STRAIN: A BIO-ECONOMIC ANALYSIS
}

\author{
M. A. Khan and F. A. Huda ${ }^{1}$ \\ Department of Department of Agricultural Finance, Bangladesh Agricultural University \\ Mymensingh-2202, Bangladesh
}

\begin{abstract}
Bangladesh Fisheries Research Institute (BFRI) has developed an improved namely, strain silver barb which shows superior performance in terms of growth and production in on-station condition. This paper analyses the comparative performance of improved silver barb strain on an average as well as on an efficient farm. Ordinary least squares regression and tobit models are estimated on an average weight at harvest and the survival rate, respectively to assess the comparative performance of the improved silver barb strain on an average farm. Stochastic frontier functions for weight at harvest are also estimated to assess the comparative performance of the improved strain on an efficient farm. The result shows a superior performance of the genetically improved silver barb strain compared to traditional strain on both average and efficient farms. On an average farm, the improved silver barb strain gives $25 \%$ higher body weight at harvest. The breakeven price above variable cost is $4.71 \%$ lower for the improved strain. The result shows that the improved silver barb strain has higher potential yield and average yield than the traditional strain.
\end{abstract}

Key Words: Silver barb, Bio-economic mode, Bangladesh

\section{INTRODUCTION}

Silver barb (Barbodes gonionotus) has been one of the most popular cultured freshwater fish species in many countries, especially in Southeast Asia (Chaudhary et al., 2008; Sarker et al, 2002 and Alim et al., 1998). During last few years, the silver barb (local name Thai punti) became an important fish species for aquaculture in Bangladesh. This species is characterized as first growth rate, easy and year-round reproduction and adaptability to a wide range of culture condition (Hossain 1989). Although the Thai Punti was first introduced in the country in 1977, no effort was initially made to develop breeding and culture technology. Silver barb production was only 0.81 percent of total pond fish aquaculture in Bangladesh (DOF, 2010). Since 1987/88, the Bangladesh Fisheries Research Institute (BFRI) at its Freshwater Station (FS), Mymensingh has pioneered the breeding

1 Associate Professor, Department of Agricultural Economics, Bangladesh Agricultural University, Mymensingh-2202, Bangladesh 
134 Comparative performance between genetically improved and traditional silver barb strain

and culture technology of fish in Bangladesh. BFRI has achieved tremendous success to produce and culture of silver barb fish species. The fish could profitably be cultured in seasonal (roadside ditches, back yard ponds and in rice field) and perennial (tanks and ponds) water bodies often in combination with other carp species. Culture of silver barb is increasing day by day in the rural pond of Bangladesh. Genetic stock improvement is the prerequisite to expand any fish species. Keeping this in mind, Bangladesh Fisheries Research Institute, Freshwater Station, Mymensingh has initiated genetic selection for stock improvement under the World Fish Center/ADB assisted project "Genetic Improvement of Carp Species in Asia" which was started in 1996. This study evaluates the on-farm production performance of improved (BFRI introduced) and traditional silver-barb strain.

\section{DATA}

This research is conducted jointly by BFRI and Bureau of Socioeconomic Research and Training, Bangladesh Agricultural University (BSERT), Mymensingh. BFRI performed the biological part of the research project and BSERT evaluated the economic part of this research. A total of 40 farms containing 20 improved and 20 traditional strain farmers prior put under on-farm trails by BFRI were selected from Sadar Upazila of Mymensingh district. Purposive random sampling technique was used to select for both improved and traditional strain's pond. Since, this research was based on field experiment; therefore, data were collected according to BFRI time schedule. Feed and fertilizer were supplied by BFRI to all farmers (improved and traditional). Accordingly, these data were collected from BFRI record book and the researchers also rechecked it at farm level.

\section{EMPIRICAL MODELS}

\section{Comparative performance of the silver barb strain on an average farm}

Production per unit area or yields of a silver barb depends on the stocking density, average weight at harvest (growth rate) and survival rate. The average weight and the survival rate depend on the levels of inputs use, production environment and genetic characteristics of the strain used. Regression models for average weight at harvest and the survival rate were estimated from the on-farm trial data. For the improved and traditional silver barb strain, the same explanatory variables were used in the regression analysis. The production function for average weight at harvest and the survival rate are as follows:

$\operatorname{Ln}(W i)=a_{0}+a_{1} \operatorname{Ln}\left(X_{1 i}\right)+a_{2} \operatorname{Ln}\left(X_{2 i}\right)+a_{3} \operatorname{Ln}\left(X_{3 i}\right)+a_{4} \operatorname{Ln}\left(X_{4 i}\right)+a_{5} \operatorname{Ln}\left(X_{5 i}\right)$

$+a_{6} \operatorname{Ln}\left(X_{6 i}\right)+a_{7} G D_{i}+a_{72} \operatorname{Ln}\left(X_{2 i}\right)^{*} G D+a_{73} \operatorname{Ln}\left(X_{3 i}\right)^{*} G D$

$S R_{i}=\beta_{0}+\beta_{1} \operatorname{Ln}\left(X_{1 i}\right)+\beta_{2} \operatorname{Ln}\left(X_{2 i}\right)+\beta_{3} \operatorname{Ln}\left(X_{3 i}\right)+\beta_{4} \operatorname{Ln}\left(X_{4 i}\right)+\beta_{5} \operatorname{Ln}\left(X_{5 i}\right)+$

$\beta_{6} \operatorname{Ln}\left(X_{6 i}\right)+\beta_{7} G D_{i}$ 
Where the subscript $i$ refers to the $i^{\text {th }}$ pond; $L n$ represents natural logarithm; $W$ represents weight of fish harvest (gm/fish); SR represents survival percentage [i.e., (number of harvested/number stocked)*100; $X_{1}$ represents fingerling size $\left(\mathrm{cm} /\right.$ fingerling); $X_{2}$ represents protein per fish $(\mathrm{gm} / \mathrm{fish} / \mathrm{ha}) ; X_{3}$ represents NPK rate $(\mathrm{gm} / \mathrm{fish} / \mathrm{ha}) ; \mathrm{X}_{4}$ represents lime $(\mathrm{gm} / \mathrm{fish}) ; X_{5}$ represents culture duration or rearing period (days); $X_{6}$ represents average water depth (m); GD is the binary improved dummy ( 1 if improved strain and 0 otherwise); $\alpha_{s}$ and $\beta_{\mathrm{s}}$ are the parameters to be estimated.

The equations on average weight at harvest (equation 1 and 2) include improved dummy variables in such a way that non-neutral technical change with respect to feed and fertilizer use is specified. However, the improved strain would be neutral if the coefficient of the interactions between improved dummies and feed/fertilizer variables are zero. The null hypothesis that the improved strain is neutral with respect to feed and fertilizer can be expressed as (in equation 1):

$\mathrm{H}_{0}: \mathrm{a}_{72}=\mathrm{a}_{73}=0$.

We also test the null hypothesis that there is no shift in the intercepts of the production functions due to the use of improved strain by an average farm. This hypothesis is expressed as $\mathrm{H}_{0}: \mathrm{a}_{7}=0$

There are many functional forms that can be used to specify the equations on average weight at harvest and on survival, we have used the simple double logarithmic forms and dummy variables are not in log forms.

\section{Comparative performance of the improved silver barb strain on an efficient farm}

The management of productive efficiency of a farm relative to other farms or to the best practice in an industry has long been of interest to agricultural economists. Efficiency measurement has received considerable attention from both theoretical and applied economists. From theoretical point of view, there has been a spirited exchange about the relative importance of various components of firm efficiency (Leibenstein, 1966, 1977; Comanor and Leibenstein 1969 and Stigler, 1976). From an applied perspective, measuring efficiency is important because this is the first step in a process that might lead to substantial resource savings. These resource savings have important implications for both policy formation and farm management (Bravo-Ureta and Rieger 1991). Farrell's (1957) seminar article on efficiency measurement led to the development of several approaches to efficiency and productivity analysis. Among these the stochastic frontier production (Aigner et al., 1977; Meeusen and van den Broeck, 1977) and Data Envelopment Analysis (DEA) are the two principal methods. As noted by Coelli et al. (1998), the stochastic frontier is considered more appropriate than DEA in agricultural applications, especially in developing countries, where the data are likely to be heavily influenced by measurement errors and the effects of weather conditions, diseases, etc. This also applies to the application of frontier techniques to fish culture. In the present study, stochastic frontier functions of average weight at harvest are estimated for silver barb. The basic stochastic frontier model used in the study is as follows: 
136 Comparative performance between genetically improved and traditional silver barb strain

$$
\begin{aligned}
\operatorname{Ln}\left(W_{i}\right)= & \gamma_{0}+r_{1} \operatorname{Ln}\left(X_{1 i}\right)+r_{2} \operatorname{Ln}\left(X_{2 i}\right)+r_{3} \operatorname{Ln}\left(X_{3 i}\right)+r_{4} \operatorname{Ln}\left(X_{4 i}\right)+r_{5} \operatorname{Ln}\left(X_{5 i}\right)+ \\
& r_{6} \operatorname{Ln}\left(X_{6 i}\right)+r_{7} G D_{i}+r_{72} \operatorname{Ln}\left(X_{2 i}\right)^{*} G D+r_{73} \operatorname{Ln}\left(X_{3 i}\right)^{*} G D+V_{i}-U_{i}
\end{aligned}
$$

Where $\mathrm{W}$ is average weight of fish harvest, and Xs and GDs are inputs and production environment related variables, respectively as defined earlier. $\gamma_{s}$ are parameters to be estimated; $\mathrm{V}$ is a two-sided, normally distributed random variable $\mathrm{V} \sim \mathrm{N}\left(0, \sigma_{\mathrm{v}}{ }^{2}\right)$ and independent of $U$; $U$ is a one- sided non-negative random variable and is usually assumed to follow one of the three possible distributions: (a) half-normal $\left[\mathrm{N}\left(0, \sigma_{\mathrm{u}}^{2}\right)\right]$; (b) truncated normal at zero $\left[\mathrm{N}\left(\mu_{\mathrm{u}}, \sigma_{\mathrm{u}}^{2}\right)\right]$; (c) exponential $\left[\mathrm{E}\left(\mu_{\mathrm{u}}, \sigma_{\mathrm{u}}^{2}\right)\right]$, where $\mathrm{E}$ indicates exponential distribution.

The null hypothesis that the technical change related to the improved silver barb strain is neutral with respect to feed and fertilizer use on the efficient farm is expressed $H_{0}: \gamma_{72}=\gamma_{73}$ $=0$. Again, in the study we test the null hypothesis that there is no shift in the intercept of the frontier production function. This hypothesis is expressed by $\mathrm{H}_{0}=\gamma_{7}=0$. The parameters of the stochastic frontier model are estimated by the method of maximum likelihood, using the frontier 4.1 package.

\section{RESULTS AND DISCUSSION}

The improved and traditional fish farmers maintained more or less the same management practices but there found a variation in level of input use, fingerling size, stocking density and husbandry practices. In this culture system, the average weight of silver barb at harvest was higher for improved strain than the traditional strain and it was statistically significant. The stocking density, fingerling size, rearing duration and the energy supply were more or less same for traditional and improved strain and the different were insignificant. But the yield of the improved variety was higher than the traditional strain and the difference was statistically significant. In terms of survival, there was no significant difference in improved and traditional strains (Table 1).

The additional inputs have been supplied by the farmers both in improved and traditional strains during the culture period. The total variable cost incurred in improved strain was much higher than that of traditional strain. Overall results indicate that the breakeven price at variable cost (i.e., variable cost of production per $\mathrm{kg}$ of fish produced) is 4 percent higher for the traditional strain than those of improved strains (Table 2).

\section{OLS regression estimates of the average weight at harvest and tobit for survival rate}

The estimated average weight at harvest and survival functions for silver barb production based on on-farm trials defined by equation 2 and 3 are given in table 3 . Ordinary Least Square (OLS) regression has done in two ways, one is on the basis on neutral technical change (Model 1) and another is non- neutral technical change (Model 2). The coefficients of technology dummy were positive in both model and it was statistically significant in neutral technical change. Fingerlings size and cultural duration were also statistically significant with positive coefficient both in neutral and non-neutral technical change. 
Table 1. Culture system, input use level and relative performance of the improved and traditional strain of silver barb under on-farm trials

\begin{tabular}{l|c|c|c|c|c|c|c|c|c}
\hline $\begin{array}{c}\text { Production } \\
\text { place }\end{array}$ & Strain & $\begin{array}{c}\text { No. of } \\
\text { trials }\end{array}$ & $\begin{array}{c}\text { Stocking } \\
\text { Density } \\
(\mathrm{no} / \mathrm{ha})\end{array}$ & $\begin{array}{c}\text { Fingerling } \\
\text { size }(\mathrm{cm} .)\end{array}$ & $\begin{array}{c}\text { Culture } \\
\text { duration } \\
(\text { days })\end{array}$ & $\begin{array}{c}\text { Protein } \\
(\mathrm{gm} / \text { fish) }\end{array}$ & $\begin{array}{c}\text { Average } \\
\text { weight at } \\
\text { harvest } \\
(\mathrm{gm} / \mathrm{fish})\end{array}$ & $\begin{array}{c}\text { Survival } \\
\text { rate }(\%)\end{array}$ & $\begin{array}{c}\text { Yield } \\
(\mathrm{kg} / \mathrm{ha})\end{array}$ \\
\hline Pond & Improved & 20 & 10799 & 4.2 & 230 & 136.39 & 186 & 88 & 2333 \\
& Traditional & 20 & 10784 & 4.4 & 233 & 135.11 & 156 & 87 & 2151 \\
Difference & & & 15 & 0.2 & -3 & 1.28 & $30^{* * *}$ & 1 & $182^{* * *}$ \\
\hline
\end{tabular}

Source: Authors own calculation, 2008, Note: ${ }^{* * *}$ indicates significant at $1 \%$ level.

Table 2. Yield and variable costs of silver barb culture using improved and traditional carp strains in ponds in on-farm trials

\begin{tabular}{lcc}
\hline \multicolumn{1}{c|}{ Item } & Improved & Traditional \\
\hline Yield $(\mathrm{kg} / \mathrm{ha})$ & 2333 & 2151 \\
Variable cost $(\mathrm{Tk} . / \mathrm{ha})$ & 62710 & 60669 \\
Breakeven price at variable cost $(\mathrm{Tk} . / \mathrm{kg})$ & 26.88 & 28.21 \\
\hline$\%$ difference $\left\{\left(\right.\right.$ Improved - traditional)/traditional ${ }^{*} 100$ & & \\
Yield & & 8.5 \\
Variable cost & 3.36 \\
Breakeven price at variable cost & -4.71 \\
\hline
\end{tabular}

Source: Authors own calculation, 2008

\section{Test of hypothesis regarding the nature of the improved technology on an average farm}

In this study, F-test of null hypothesis has been done and the results are presented in Table 4. At first, the null hypothesis has been rejected for the 'no technical change' and it was statistically significant that is the improved technology (improved silver barb strain) has significant impact on the average weight of the output. The null hypotheses of neutral technology change with respect to protein and NPK use on an average farm is also rejected which is statistically significant. It implies that the output of improved strain has increased than traditional strain due to use of feed protein and NPK. In other words, the improved strain silver barb producer get more output than the traditional silver barb strain producer with the use of same protein and NPK. So, it may be concluded that the improved variety is very good genetic quality.

Test on intercept shift of the average weight at harvest function has been done (Table 4). The test result indicates that the upward shift in the average weight at harvest function due to use of the improved strain is statistically significant and null hypothesis is rejected.

After accounting the wide homogeneity of production environments, input levels, and other factors, the average weight at harvest of genetically improved silver barb strain was more than 25 percent higher than the traditional strain which was also statistically 
138 Comparative performance between genetically improved and traditional silver barb strain

significant. Therefore, it can be concluded that there is no significant difference in survival rate of improved and traditional silver barb strains (Table 5).

Table 3. Ordinary least square estimates of the average weight and survival model for silver barb production under on- farm conditions in Bangladesh

\begin{tabular}{|c|c|c|c|c|c|}
\hline \multirow[t]{3}{*}{ Variables } & \multicolumn{3}{|c|}{ Ln (weight at harvest) } & \multicolumn{2}{|c|}{ Survival } \\
\hline & \multirow[t]{2}{*}{ Parameters } & \multicolumn{2}{|c|}{ Estimates coefficient } & \multirow[t]{2}{*}{ Parameters } & \multirow{2}{*}{$\begin{array}{l}\text { Estimated } \\
\text { coefficient }\end{array}$} \\
\hline & & Model 1 & Model 2 & & \\
\hline Intercept & $\mathrm{a}_{0}$ & $\begin{array}{c}-21.57^{* * *} \\
(7.22)\end{array}$ & $\begin{array}{c}-21.00^{* * *} \\
(7.74)\end{array}$ & $\beta_{0}$ & $\begin{array}{c}57.62 \\
(132.73)\end{array}$ \\
\hline Ln ( Fingerling size) & $\mathrm{a}_{1}$ & $\begin{array}{c}0.51^{* * *} \\
(0.12)\end{array}$ & $\begin{array}{c}0.48^{* * *} \\
(0.15)\end{array}$ & $\beta_{1}$ & $\begin{array}{r}-15.49 \\
(9.86)\end{array}$ \\
\hline Ln (protein per fish) & $\mathrm{a}_{2}$ & $\begin{array}{l}-0.21 \\
(0.17)\end{array}$ & $\begin{array}{l}-0.22 \\
(0.25)\end{array}$ & $\beta_{2}$ & $\begin{array}{l}-4.63 \\
(4.67)\end{array}$ \\
\hline Ln (NPK) & $a_{3}$ & $\begin{array}{l}-0.057 \\
(0.04)\end{array}$ & $\begin{array}{l}-0.07 \\
(0.05)\end{array}$ & $\beta_{3}$ & $\begin{array}{l}1.15 \\
(1.08)\end{array}$ \\
\hline Ln (Lime) & $\mathrm{a}_{4}$ & $\begin{array}{c}0.015 \\
(0.004)\end{array}$ & $\begin{array}{c}0.02 \\
(0.05)\end{array}$ & $\beta_{4}$ & $\begin{array}{l}-1.07 \\
(1.79)\end{array}$ \\
\hline Ln ( Culture duration) & $a_{5}$ & $\begin{array}{c}5.37^{* * *} \\
(1.40)\end{array}$ & $\begin{array}{c}5.27^{* * *} \\
(1.56)\end{array}$ & & $\begin{array}{c}15.51 \\
(22.36)\end{array}$ \\
\hline Ln ( Water depth) & $\mathrm{a}_{6}$ & $\begin{array}{c}0.09 \\
(0.16)\end{array}$ & $\begin{array}{c}0.12 \\
(0.18)\end{array}$ & $\beta_{5}$ & $\begin{array}{l}-2.48 \\
(9.06)\end{array}$ \\
\hline Technology dummy & $a_{7}$ & $\begin{array}{l}0.25^{* * *} \\
(0.07)\end{array}$ & $\begin{array}{c}0.18 \\
(1.77)\end{array}$ & $\beta_{7}$ & $\begin{array}{l}9.83^{* *} \\
(3.77)\end{array}$ \\
\hline $\begin{array}{l}\text { Ln (protein/fish) } \times \\
\text { improved dummy }\end{array}$ & $\mathrm{a}_{72}$ & & $\begin{array}{l}0.001 \\
(0.36)\end{array}$ & $\beta_{72}$ & \\
\hline $\begin{array}{l}\text { Ln }(\mathrm{NPK} / \text { fish }) \times \text { improved } \\
\text { dummy }\end{array}$ & $a_{73}$ & & $\begin{array}{c}0.04 \\
(0.08)\end{array}$ & $\beta_{73}$ & $6.80^{* *}$ \\
\hline Number of observation & & 40 & 40 & & \\
\hline $\mathrm{R}^{2}$ & & 0.57 & .58 & & \\
\hline F-value & & $6.31^{* *}$ & $4.68^{* *}$ & & \\
\hline
\end{tabular}

*** Significant at $1 \%$ level, ** Significant at 5\% level, * Significant at $10 \%$ level; The figure in parentheses are standard error of the respective coefficient estimates.

\section{Stochastic yield frontier for improved and traditional silver barb strains}

Stochastic frontier functions of body weight at harvest are estimated for the improved and traditional silver barb strains. The survival rates of improved and traditional strains are not significantly different. Table 6 shows that the coefficient of fingerling size, cultural duration and protein (improved dummy) were positively significant. 
Table 4. F-test of hypotheses involving some of the estimates of the average weight function for average farms

\begin{tabular}{l|c|c|c|c}
\hline \multicolumn{1}{c|}{ Null hypothesis $\left(\mathrm{H}_{0}\right)$} & $\begin{array}{c}\text { Degree of } \\
\text { freedom }\end{array}$ & $\begin{array}{c}\text { Test statistic } \\
(\mathrm{F}-\text {-value })\end{array}$ & $\begin{array}{c}\text { Critical } \\
\text { value }(5 \%)\end{array}$ & Decision \\
\hline $\begin{array}{l}\text { Test on no technical change } \\
\mathrm{H}_{0}: \mathrm{a}_{7}=\mathrm{a}_{72}=\mathrm{a}_{73}=0 .\end{array}$ & 3,30 & 3.59 & 2.92 & Rejected \\
$\begin{array}{l}\text { Test on neutral technical change } \\
\text { (Test of slope shift) }\end{array}$ & 2,30 & 6.31 & 3.32 & Rejected \\
$\mathrm{H}_{0}: \mathrm{a}_{72}=\mathrm{\alpha} 73=0$ & & & & \\
$\begin{array}{l}\text { Test on intercept shift } \\
\mathrm{H}_{0}: \mathrm{a}_{7}=0\end{array}$ & 1,30 & 5.44 & 4.17 & Rejected \\
\hline
\end{tabular}

Table 5. Percentage increase in average weight at harvest and survival rate due to the use of the improved strain compared to traditional strain on average farm

\begin{tabular}{c|c|c}
\hline Generation of improved strain & $\begin{array}{c}\text { Average weight } \\
(\% \text { increase })\end{array}$ & $\begin{array}{c}\text { Survival } \\
(\% \text { increase })\end{array}$ \\
\hline F-7 & $25^{* * *}$ & NS \\
\hline
\end{tabular}

*** Significant at $1 \%$ level

\section{Tests of hypotheses regarding the nature of improved and traditional strains}

Generalized likelihood ratio test of null hypotheses using stochastic frontier model has presented in Table 7. The result of the null hypotheses for body weight on efficient farms and the average weight at harvest (OLS) are of same pattern but only difference in intercept change. The null hypothesis on 'no technical change' was rejected and statistically significant at $1 \%$ level. The test on neutral technology change was rejected i.e., both average and efficient farms is non- neutral with respect to use of protein and NPK. It may be generalized that the nature of the improved strain with respect to protein and NPK use will be similar on both average and efficient farms in Bangladesh. The findings of the log-likelihood ratio tests on the intercept shift of the stochastic body weight at harvest due to the use of improved strain shows that the upward shift in the intercept is not significant.

\section{Average and frontier yield}

The yield of the improved silver barb on efficient and average, given the average farmer's input production environment, are calculated based on the frontier body weight production function and average body weight equation (OLS estimate), respectively. Yield of traditional strain on efficient and average farms are also calculated. It is assumed that the stocking density would be 12000 fish/ha with survival rate 90 percent. The result (Table 8 ) shows that the improved silver barb strain has higher potential yield and average yield than the traditional strain. 
140 Comparative performance between genetically improved and traditional silver barb strain

Table 6. Maximum-likelihood estimates of stochastic body weight at harvest for silver barb culture in Bangladesh

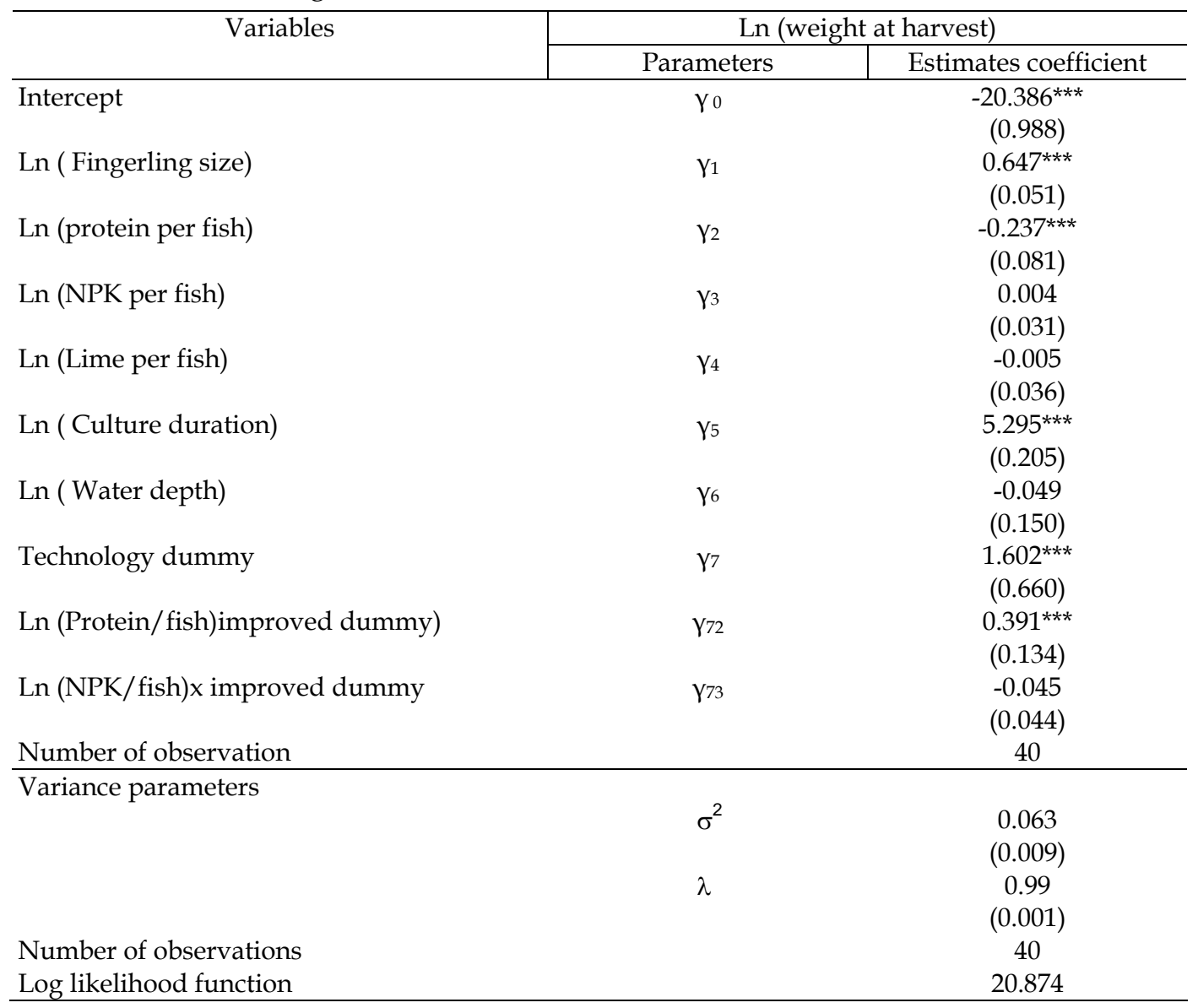

*** Significant at $1 \%$ level, (Figure in the parentheses indicate standard error)

Table 7. Generalized likelihood-ratio tests of null hypotheses involving some estimates of the stochastic frontier model for body weight at harvest on efficient farms

\begin{tabular}{l|c|c|c|c}
\hline \multicolumn{1}{c|}{ Null hypothesis $\left(\mathrm{H}_{0}\right)$} & $\begin{array}{c}\text { Degree of } \\
\text { freedom }\end{array}$ & $\begin{array}{c}\text { Test statistic } \\
(\text { F-value })\end{array}$ & $\begin{array}{c}\text { Critical } \\
\text { Value }(1 \%)\end{array}$ & Decision \\
\hline $\begin{array}{l}\text { Test on no technical change } \\
\mathrm{H}_{0}: \gamma_{7}=\gamma_{72}=\gamma_{73}=0 .\end{array}$ & 3 & $19.68^{* * *}$ & 11.34 & Rejected \\
$\begin{array}{l}\text { Test on neutral technical change } \\
\text { Test of slope shift })\end{array}$ & 2 & $5.52^{* *}$ & $\begin{array}{c}3.84 \\
(5 \% \text { critical } \\
\text { value })\end{array}$ & Rejected \\
$\mathrm{H}_{0}: \gamma_{72}=\gamma_{73}=0$ & & 1.14 & NS & Accepted \\
$\begin{array}{l}\text { Test on intercept shift } \\
\mathrm{H}_{0}: \gamma_{7}=0\end{array}$ & 1 & & & \\
\hline
\end{tabular}

${ }^{* * *}$ rejected at $1 \%$ significant level, ${ }^{* *}$ rejected at $5 \%$ significant level, NS- not significant 
Table 8. Average and maximum potential (frontier) yield of improved and traditional strains of silver barb culture system

\begin{tabular}{l|c|c|c|c}
\hline \multirow{2}{*}{ Category } & \multicolumn{2}{c|}{$\begin{array}{c}\text { Potential yield }{ }^{1} \\
(\mathrm{~kg} / \mathrm{ha})\end{array}$} & \multicolumn{2}{c}{$\begin{array}{c}\text { Average yield }{ }^{2} \\
\text { (kg/ha) }\end{array}$} \\
\cline { 2 - 5 } & Improved & Traditional & Improved & Traditional \\
\hline Neutral technical change & 2592 & 2388 & 2487 & 2291 \\
Non-neutral technical change & 2689 & 2443 & 2483 & 2288 \\
\hline
\end{tabular}

${ }^{1}$ Calculated based on the frontier and average survival rate functions assuming an average stocking density 12000 fish/ha and 90\% survival rate.

${ }^{2}$ Calculated based on the average weight and survival rate functions assuming an average stocking density $12000 \mathrm{fish} /$ ha and $90 \%$ survival rate.

\section{CONCLUSION}

Silver barb at present is a popular species to the fish farmers of Bangladesh because it grows well on low protein diets, able to take food at any water level and can tolerate a wide range of environmental conditions. Bangladesh Fisheries Research Institute (BFRI) has developed an improved strain silver barb which shows superior performance in terms of growth and production in on-station condition. This paper analyses the comparative performance of improved silver barb strain on an average as well as on an efficient farm. Yield of improved variety or strain was higher than traditional ones at same level of input use and cultural practices and variation was found significant. Breakeven price at variable cost (i.e. variable cost of production per kilogram of fish produced) was $4 \%$ higher in case of traditional strain than those of improved silver barb strains. The results showed that improved silver barb strain gave 25 percent higher body weight at harvest than the traditional strain. The improved strain of silver barb gave higher yield compared to the traditional strains on both the average and efficient farmers. At a given production environment and input level, the yield of the improved strain on an average farm was higher than the maximum possible (i.e. on the most efficient farm) of the traditional strain. This implies that the adoption of the improved strain can increase productivity of the silver barb culture even with the present level of farmers' efficiency.

\section{REFERENCES}

Aigner, D. J., Lovell, C. A. K. and Schmidt, P. 1977. Formulation and estimation of stochastic frontier production function models. J. Econ., 6: 21-37.

Alim, M. A., Chowdhury M. M. H. and Nabi, S. M. N. 1998. Polyculture of fish (Labeo rohita, Hypophthalmichthys molitrix and Puntius gonionotus) with prawn (Macrobrachium rosenbergii) in gher farming systems. Paper presented in $3^{\text {rd }}$ ANR Aquaculture and Fisheries Workshop, 4-5 October, Dhaka, Bangladesh, arranged by CARE Bangladesh.

Bravo-Ureta, B. E, and Rieger, L. 1999. Dairy Farm Efficiency Measurement Using Stochastic Frontier and Newclassical Duality. American J. Agric. Econ._ 53(2): 421-428. 
142 Comparative performance between genetically improved and traditional silver barb strain

Chaudhary, S., Shrestha, M., Jha D. and Pandit, N. 2009. Growth performance of silver Barb (Puntius gonionotus) in mono and polyculture Systems. Our Nature, 6: 38-46.

Coelli, T. J., and Battese, G. E. 1998. An Introduction of Efficiency and Productivity Analysis. Kluwer Academic Publishers, Boston, USA.

Comanor, W. S. and Leibenstein, H. 1969. Allocative Efficiency, 'X-Efficiency and the Measurement of welfare Losses, Economica, 36: 304-309.

DoF, 2009-10. Fisheries Statistical Yearbook of Bangladesh., Department of Fisheries, Ministry of Fisheries and Livestock, Dhaka, Bangladesh.

Hussain, M. G., Akteruzzaman, M., Kohinoor A. H. M and Shah, K. A. 1989. Semi intensive culture of silver barb. J. Fish 12: 32-38.

Leibenstein, H. 1966. Allocative Efficiency VS 'X-Efficiency. American Economic Review, 56: 392-415.

Leibenstein, H. 1977. X-Efficiency, Technical Efficiency and Incomplete Information Use: A Coment. Economic Development and Cultural Change: 25: 311-316.

Stigter, C. J. 1976. The Existence of 'X-Efficiency. American Economic Review, 66: 213-226.

Meesusen, W. and van den Broeck, J. 1977. Efficiency estimation from Cobb-douglas production functions with composed errors. International Economic Review, 18: 435-444.

Sarker, P. K., Chowdhury, B. B. P., Khan M. S. A., Pal, H. K. and Mondal, S. 2002. A Study on Silver barb (Puntius gonionotus) Monoculture Vs. Mixed Culture with Carp (Cyprinus carpio) in the Yard Ditches of Bangladesh. Online Journal of Biological Sciences, 2(4): 230-231. 